86 JOURNAL OF AGRICULTURE OF UNIVERSITY OF PUERTO RICO

\title{
BACTOCERA RUBRA LINNAEUS IN PUERTO RICO
}

Batocera rubra Linnaeus, a large grey cerambycid beetle more than 2 inches long, previously recorded only from St. Croix and Barbados in the West Indies, and from China where it is presumably endemic, is now known to occur in Puerto Rico. Don Julio García-Diaz found the first Puerto Rican specimen, identified by George B. Vogt of the U. S. National Museum, in July 1954, at Sardinera, a little fishing village north-east of Fajardo. Duplicate specimens were also collected recently in St. Croix by George A. Seaman, Wild Life Supervisor of the Virgin Islands, possibly indicating such abundance there as to stimulate migration to adjacent islands, if the Puerto Rican record is not of an accidental introduction in commerce. The beetle is characterized by a conspicuous large white scutellum, broad-based lateral spines on the prothorax, and stout, dark antennae considerably longer than the body. 